\title{
Higher Education in Resource-Type Regions
}

\author{
Margarita V. Kurbatova and Inna V. Donova* \\ Kemerovo State University \\ 6 Krasnaya Str., Kemerovo, 650043, Russia
}

Received 19.09.2019, received in revised form 03.12.2019, accepted 09.12.2019

Currently, attention to regional economies of resource type is on the rise. Many papers dealing the "resource curse" problem discuss the mechanisms forming a trap of human capital underdevelopment. This article is an attempt to find out whether resource dependence of the region affects the development of regional higher education systems and the characteristics of high-quality accumulated human capital. The basis for this study is a fuzzy typology of the Russian regions based on two indicators: the share of extractive industries in GRP, the ratio of the shares of extractive and manufacturing industries, and the calculation of a comprehensive assessment of resource dependence (on the scale from 0 to 10). The calculations made it possible to identify 27 resource-type regions. The authors analyzed the indicators of the educational level of the employed population and the peculiarities of its use (accumulated human capital), the number of university students (human capital flow), as well as dependence of the reduction in the number of academic staff and growth in their salaries on the level of the region's resource dependence. The study found dependence in the use of high-quality human capital on the resource specialization of the regions. It is manifested in a fairly high educational level of the workforce employed in mining industries and in the public sector, as well as with specialized training. Moreover, based on the levels of changes in the number of faculty and growth of their salaries, it is possible to observe an increase in the uneven development of the education systems of the resource-type regions, deepening differentiation of universities downshifting most of them towards the periphery of the educational space with a shortage of human and other resources.

Keywords: higher education, resource-type regions, human capital, employment structure.

This research is supported by the Russian Foundation for Basic Research (RFBR), Grant No. 19-010-00244 "Institutional setup of the labor market in resource type regions".

Research area: economics.

Citation: Kurbatova, M.V., Donova, I.V. (2019). Higher education in resource-type regions. J. Sib. Fed. Univ. Humanit. Soc. Sci., 12(12), 2217-2229. DOI: 10.17516/1997-1370-0520.

(C) Siberian Federal University. All rights reserved

* Corresponding author E-mail address: idonova@gmail.com ORCID: 0000-0001-9370-5402 (Donova)

This work is licensed under a Creative Commons Attribution-NonCommercial 4.0 International License (CC BY-NC 4.0). 


\section{Introduction}

In today's Russia, regions differ significantly in terms of specific resource and industry patterns and institutional organization of their economy. At the same time, gaps are widening within the country's economic space and in economic development of numerous regions that are weakly connected with each other by value chains. Applied to the sphere of employment and labour market, this means that the national Russian labour market acts as a set of regional markets interconnected only partially and differing in the sectoral structure of employment, as well as in actors and game rules. Of particular importance here are peculiarities of the institutional organization of regional labour markets and the mechanisms for their adaptation to technological and economic changes. This has a significant impact on the pace of job creation, formation of unemployment, economic conditions for employees, as well as their economic and social well-being.

The institutional organization of labour markets in resource-type regions is of particular interest. In this paper, the authors regard resource-type regions as those characterised not only by high resource availability, but also by a certain degree of resource dependence. This is a specific challenge for the Russian economy. It lies in the fact that these regions are most susceptible to fluctuations in the world market conditions and the risks of deepening technological gaps with the most developed regions of the Russian and world economies. Special mechanisms for adapting regional labour markets to external shocks have been formed in the risky environment of the resource-type regions and, at the same time, the adaptation of these markets to long-term changes caused by technological, structural and social shifts remains a serious unresolved problem. In turn, long-term changes in labour markets are closely related to the process of human capital accumulation and the situation in regional systems of higher education.

At present, the educational space of the Russian Federation is also undergoing differentiation due to the implementation of various projects aimed at stratification of Russian universities and concentration of financial resources in universities of higher status. This is intended to increase international competitiveness of Russian higher education. The flows of not only financial resources, but also human capital from the regions to the centre are being formed. In this regard, the following research questions arise: does the development of regional higher education systems depend on the level of resource dependence of the region? What happens to these systems under the conditions of the ongoing reform of Russian higher education? And how does this affect the labour markets? 


\section{Theoretical framework}

The abundance of resources creates both opportunities and threats to the economic development of resource-type territories. In the literature dealing with the impact of resource availability and resource dependence on economic development, this problem is most often referred to as a "resource curse", which involves the phenomenon of lower growth rates demonstrated by countries rich in natural resources, compared with countries that do not possess them.

The research tradition of analysing the relationship between the level of human capital development and the problem of the "resource curse" originated long ago in the context of studying the factors of uneven economic development. Researchers identified several ways of the negative impact of "resource wealth" on economic development including degradation of institutions and reduction of incentives for the accumulation of physical and human capital. Studies (Rolfe et al., 2007; Franks, Brereton, Moran, 2010; Evans and Sawyer, 2009) show that mining activities bring both positive (growth incomes of the local population, poverty reduction, increased employment in local small businesses) and negative (increased crime, increased load on the local social infrastructure) consequences. In their works, Leamer et al. (Leamer et al., 1999; Bravo-Ortega, de Gregorio, 2005) demonstrate how the effect of the resource curse is realized through the mechanism of human capital accumulation. It should be noted that the findings of these studies concern only high-quality human capital and point to the fact that in resource economies there is a trap of highly skilled labour resources underdevelopment.

Currently, the focus of attention is shifting from the level of national economies to the studies of regional labour markets in resource-type regions. This is especially relevant for Russia, which is characterised by a significant heterogeneity of the labour market in terms of economic and geographical features of individual regions. This Russian peculiarity challenges the very idea of a single national labour market and leads experts to viewing it as a system of individual regional markets. In the recent studies of Russian researchers there were attempts to assess the impact of the share of the region's population with higher education on unemployment rate (Semerikova, Demidova, 2016), to analyze the relationship between the indicators of educational development (including per capita education expenditures of regional budgets) and indicators of resource dependence (Vasilyeva, 2012). 


\section{Statement of the problem}

The research question is whether resource dependent regions are distinguished from other regions by the educational level of the employed population (accumulated human capital used in the economy), by the number of university students (human capital flow), and other characteristics of regional educational systems.

The problem is that in recent years, centripetal trends have been recorded in the distribution of universities and academic staff among the regions. This is a clear sign of the growing uneven distribution of human capital by the regions, a factor of further rise in the disparity of their social and economic development. In this regard, it is important to understand whether the loss of students and faculty, achievement of target salary level and difference in the educational characteristics of those, employed in regional labour markets in the resource-type regions, are more or less significant compared to the average ones for Russia.

The hypothesis of this study is formulated as follows: the level of resource dependence in the region has a generally negative impact on the development of regional higher education systems. This is manifested in a number of characteristics of the employment structure, in a smaller number of university students per 10 thousand of population, and in reduction in the number of academic staff at universities.

\section{Methods}

This study is based on the developed fuzzy typology of the Russian regions based on two indicators (the share of mining industries in GRP and the ratio of the shares of mining and manufacturing industries in GRP, according to the data of 2016) and the calculation of a comprehensive assessment of resource dependence CArd (on the scale from 0 to 10). The calculations conducted made it possible to divide the Russian regions into those of resource type (27 regions) and non-resource type (58). A comprehensive assessment of resource dependence of the regions identified as resource type ones is above 5.0. 10 federal entities that are not included in the resource type regions have a comprehensive assessment of the resource dependence ranging from 0.16 to 4.23 , the rest of them -0 .

4 groups of regions were identified among the resource-type regions: 7 regions of a very high level of resource dependence (Nenets Autonomous Okrug, Chukotka Autonomous Okrug, the Republic of Sakha (Yakutia), Khanty-Mansi Autonomous Okrug - Yugra, Yamalo-Nenets Autonomous Okrug, Magadan Oblast and Sakhalin Oblast) with a comprehensive assessment of resource dependence in the range from 
9.25 to 10; 6 regions of high-level resource dependence (Trans-Baikal Krai, the Komi Republic, Tomsk Oblast, Orenburg Oblast, Irkutsk Oblast, Kemerovo Oblast) with a comprehensive assessment in the range from 7.26 to 7.91; 11 regions of middle-level resource dependence (Murmansk Oblast, the Republic of Tatarstan, the Udmurt Republic, Tyumen Oblast without autonomous okrugs, the Republic of Khakassia, Kamchatka Krai, the Republic of Karelia, Samara Krai, Krasnoyarsk Krai, Perm Krai, and Belgorod Oblast) with a comprehensive assessment in the range from 5.44 to 6.76; and 3 regions with a predominance of mining industries over manufacturing ones with an average share of mining industries in GRP (the Republic of Tyva, Astrakhan Oblast and Amur Oblast), whose comprehensive assessment ranges from 8.13 to 8.73. The main informative results were obtained using descriptive and regression statistical analysis.

\section{Discussion}

The results of the analysis conducted are ambiguous. This is due to the fact that the resource-type regions themselves are very differing from each other (by GRP per capita, by the level of economy diversification, and by the characteristics of regional higher education systems). Thus, Tomsk oblast stands apart in the group of regions with a high level of resource dependence, as the second in the country in terms of the number of university students per 10 thousand of population. Table 1 shows some indicators reflecting the educational characteristics of the population in regions of various types and number of students getting Bachelor's, Specialist's, and Master's degree.

Evidently, the educational structure of those employed in the regions with a very high level of resource dependence is concentrated at two opposites - higher education and secondary general education (due to the relatively low share of employees with vocational education). The authors' calculations for 2017 based on the microdata of the Labour Force Survey conducted by Rosstat (Russian Statistics Agency) gave an opportunity to conduct more detailed comparisons of the regions according to the educational characteristics of the employed. Thus, in the regions with very high resource dependence, the share of people employed with education above the Bachelor's degree is slightly higher than the average for Russia (26.5\% and $24 \%$, respectively). In the regions with medium resource dependence, the share of those employed with the Bachelor's degree is slightly higher than the national average (2.6\% versus $2.3 \%$ for the Russian Federation). It is of interest that evaluating the connection between 
Table 1. Some characteristics of the labour market in regions with different levels of resource dependence for $2017^{*}$

\begin{tabular}{|c|c|c|c|c|}
\hline & $\begin{array}{c}\text { Percentage of } \\
\text { employees aged } \\
15-72 \text { with } \\
\text { higher education }\end{array}$ & $\begin{array}{c}\text { Percentage of } \\
\text { employees aged } \\
15-72 \text { years } \\
\text { with vocational } \\
\text { education } \\
\end{array}$ & $\begin{array}{c}\text { Percentage of } \\
\text { employees aged } \\
15-72 \text { years } \\
\text { with secondary } \\
\text { general education }\end{array}$ & $\begin{array}{l}\text { Number of } \\
\text { university students } \\
\text { per } 10 \text { thousand of } \\
\text { population }\end{array}$ \\
\hline $\begin{array}{l}\text { Very high level of resource } \\
\text { dependence (CArd: } 9.25-10)\end{array}$ & 34.7 & 24.1 & 18.7 & 136.5 \\
\hline $\begin{array}{l}\text { The predominance of mining } \\
\text { industries over manufacturing } \\
\text { ones with an average share of } \\
\text { mining industries in GRP (CArd: } \\
8.13-8.73 \text { ) }\end{array}$ & 33.3 & 27.9 & 16.1 & 210.7 \\
\hline $\begin{array}{l}\text { High level of resource } \\
\text { dependence } \\
\text { (CArd: } 7.26-7.91)\end{array}$ & 29.0 & 23.8 & 18.4 & 279.3 \\
\hline $\begin{array}{l}\text { Average level of resource } \\
\text { dependence } \\
\text { (CArd: } 5.44-6.76)\end{array}$ & 31.5 & 25.3 & 17.2 & 255.5 \\
\hline $\begin{array}{l}\text { Low resource dependence } \\
\text { (CArd: } 0-4.23 \text { ) }\end{array}$ & 32.1 & 25.3 & 18.6 & 254.9 \\
\hline
\end{tabular}

*Compiled by the authors based on (Regiony Rossii: Sotsialno-ekonomicheskie..., 2018).

employment and their education, $68 \%$ of the respondents with a university degree from the regions with very high resource dependence gave positive answers (while in the non-resource regions this share is $56 \%$ ). In the other two groups of high resource dependence (Trans-Baikal Krai, the Komi Republic, Tomsk Oblast, Orenburg Oblast, Irkutsk Oblast, Kemerovo Oblast, the Republic of Tyva, Astrakhan Oblast and Amur Oblast) $20-22 \%$ of the respondents completely denied any connection between their work and education (while in non-resource regions the share of such respondents is $17 \%)$.

It was also possible to identify the specific features of using accumulated human capital in the resource-type regions. The authors' analysis of the distribution of employees with higher education by industries shows that, compared with corresponding parameters of the employment pattern in the country on average, in the regions with high resource dependence the share of such people is significantly higher in mining industry (which is to be expected), in the electric power, gas and steam supply industries, as well as in transportation and storage (obviously, due to special climatic conditions of most resource type regions). However, regions with a middle degree of resource dependence demonstrate even greater share of people with a high educational 
level in manufacturing and construction industries than in the "non-resource" regions. On the other hand, the share of such employees in trade, as well as in research and design activities is lower in the employment pattern of the resource-type regions. An increased share of highly educated workers in government and defense agencies, social welfare and education, healthcare and social services, as well as sports and culture is recorded. This is especially pronounced in two most "resource-dependent" groups of regions.

It can be stated that there is a specific pattern of jobs and positions of people with higher education in the resource type regions. Thus, in the most resourcedependent regions, the proportion of most highly educated professionals, machine operators, assemblers and drivers is higher; in the regions with the middle degree of resource dependence there are more mid-skilled professionals and skilled workers in manufacturing industry, construction and transportation.

Thus, regions with the highest comprehensive assessment of resource dependence (Nenets Autonomous Okrug, Chukotka Autonomous Okrug, the Republic of Sakha (Yakutia), Khanty-Mansi Autonomous Okrug - Yugra, Yamalo-Nenets Autonomous Okrug, Magadan Oblast and Sakhalin Oblast) are characterized by a rather high educational level of workforce employed in the mining industries and in the public sector and those with special training (working in the same field which they were trained for). These are mainly oil and gas extracting regions. As the level of resource dependence decreases, the educational characteristics of the workforce change in different fields.

In 3 regions, characterised by the predominance of mining industries over manufacturing ones with an average share of mining industries in GRP (the Republic of Tuva, Astrakhan Oblast and Amur Oblast), a higher level of stuff education is associated with a higher unemployment rate (18.5\%, $7.5 \%$, and $5.9 \%$, respectively). We can attribute this to the fact that the choice of employees is limited (mining industries or public sector require special professional training) due to the low overall level of the region's economy development. Gross regional product per capita in the Republic of Tuva, Astrakhan and Amur Oblast is 35, 70 and $76 \%$ of the average Russian indicator, respectively. In the other two groups of the resource-type regions without oil and gas extracting specialization and a more diversified structure of the economy, the educational employment pattern is closer to the non-resource regions.

In terms of the number of university students per 10 thousand of population, the resource type regions are inferior to the non-resource regions. Moreover, the level of 
resource dependence produces a clear negative effect on the number of such students in the region. A more detailed consideration of the "university student availability" in the regions demonstrates that the situation is extremely diverse among the regions with the signs of resource dependence: at one extreme, three regions (Tomsk Oblast, Tyumen Oblast without autonomous okrugs and the Republic of Tatarstan) are rated the $2 \mathrm{nd}, 6 \mathrm{th}$ and $7 \mathrm{th}$, respectively. At the other extreme, there are 17 regions of varying degrees of resource-dependence (out of 27) occupying positions in the lower half of the rating (45th position and lower), including the bottom three (85th-87th positions). The indicator of the empirical correlation ratio $(\eta)$ of the number of university students per 10 thousand of population for the CArd indicator has the value of 0.654 (with a Pearson correlation value equal to -0.157 ), which indicates the presence of a moderate negative impact of the resource dependence on the "university student availability".

Another area of research was the analysis of the dependence of the reduction in the number of academic staff and the growth in salaries of university professors on the level of resource dependence in the region. The implementation of Presidential Decree No. 597 of May 7, 2012 "On Actions to Implement National Social Policy," which established the target level for raising the salaries of public-sector workers by 2018 (the salary of academic staff were to achieve the target level of 200 per cent of the average salary in the respective region) had serious consequences for the regions. This growth was accompanied by a decrease in the number of university professors employed (Kurbatova, Donova, 2019). According to the federal statistics concerning the remuneration of certain categories of employees in the public sector and science, this reduction was up to $26.7 \%$ for the period 2013-2018 (Itogi federal'nogo statisticheskogo..., 2019).

The analysis of the decrease in the number of academic staff by 2018 (\% compared with 2013) indicates that the resource-type regions on average "decreased" the number of university professors more than the "non-resource" regions (by $35 \%$ compared to $31 \%$ in the non-resource regions). However, only a few regions provided the most significant "contribution" to the amount of this reduction — these are YamaloNenets Autonomous Okrug (80\%), as well as Magadan Oblast, the Udmurt Republic and Kamchatka Krai (47-48 \%), Kemerovo and Murmansk Oblast (which reduced their academic staff by $43-45 \%$ ). It is notable that out of 59 regions classified as "non-resource" ones, only 5 (Novgorod Oblast, Chuvashia, Dagestan, the Jewish Autonomous Oblast and Buryatia) exceeded these indicators. Descriptive statistics are partially supported by the calculation of the correlation between these indicators. 
Thus, the empirical correlation ratio $(\eta)$ of the decrease in the number of university professors (2018 in per cent to 2013) based on the CArd indicator has the value of 0.631 (with a Pearson correlation equal to -0.186), which indicates a moderate negative effect of the resource dependence on the extent of "decreasing" academic staff.

Regarding the growth in salaries in higher education institutions, a very high salary rise of academic staff in 2018 compared to 2013 was recorded in two regions of the two most resource-dependent groups: the Republic of Sakha (Yakutia) - by $236 \%$ and Astrakhan Oblast - by $231 \%$. Of the rest resource-type regions, only other four (Amur and Murmansk Oblast, Krasnoyarsk Krai and the Republic of Karelia) exceeded $200 \%$ value. However, the absolute increase in salaries in regional universities can be considered only in comparison with the growth rate of average regional wages, or a new indicator - average regional labour income. According to the data for the $1^{\text {st }}$ quarter of 2018 (the government did its best to achieve this target level before the presidential election campaign), Amur Oblast and Karelia did not achieve $200 \%$ of the average labour income in the region (as well as, by the way, other two non-resource type regions - St. Petersburg and Tyumen Oblast). It should be borne in mind that the level of both salaries and "labour incomes" in St. Petersburg and Tyumen is one and a half times higher than in the aforementioned "underdeveloped" resource-type regions ${ }^{1}$. According to the data for the first half of 2019, only 18 regions reached the target of $200 \%$ of the average regional wages (that amount is higher than the average regional labour income) (Informatsiia dlia vedeniia monitoringa ..., 2019), two of which (Perm Krai and Samara Oblast) belong to the group of regions with a middle level of resource dependence, and one (Tomsk Oblast) is characterised by its high level. Other "well-to-do" regions in terms of salaries are not classified as resource ones.

A comparison of the reduction values in the number of university professors over the past 5 years and the current ratio of their salaries to the average for the region provides fuller picture of the educational system functioning in the resource-type regions under the conditions of reforms. The achievement of the academic staff salary growth targets established by the Presidential Decree of May 2012, took place in very diverse contexts in the regions. The initial differences in the ratio of academic staff salaries to regional average salaries, as well as differences in the growth rates of regional salaries, were of importance. Based on this, to achieve the target level, universities from different regions needed various resources. Their lack led to a greater

If the average regional salary is considered as the basis for calculations, only four regions have achieved the value of $200 \%$ and exceeded it, all of them are of non-resource type. 
decrease in the number of academic staff. To analyse the regions differentiation by the growth of professors' salaries and the degree of reduction in the number of university professors, the "Comparative Excess Index", which is a quotient of two indicators growth in the average salary of university professors in the region in 2018 compared to 2013 and a similar indicator for regional average wages, was calculated. Thus, this index shows how the growth in the salaries of academic staff exceeds the growth of the average regional salary. At the same time, some regions could have high initial ratios of university professors' salaries to the average regional salaries, but the latter increased faster (for example, in Vladimir Oblast). In other regions, on the contrary, in 2013, low salaries of academic staff were recorded in comparison with the regional average, but later salaries in universities increased faster than the average salaries in the regions (for example, in Leningrad Oblast).

Considering the fact that the average value of academic staff reduction for all the studied regions, comparing with the level of 2013 , is $69 \%$, while the "comparative excess index" is $145 \%$ on average, several types of regions can be distinguished based on the combination of these indicators' levels. Significant discrepancy between the resource and non-resource regions can be seen in one case: $43 \%$ of the "resource" regions (and only $36 \%$ of the "non-resource" ones) with a relatively low excess of university salaries over the average regional salary kept the number of university professors at the level of $70 \%$ and higher. This tendency is most pronounced for Tomsk and Irkutsk Oblast, Khanty-Mansi Autonomous Okrug, and the Republic of Khakassia. It should also be noted that the most prosperous regions, where the salary of university staff over 5 years significantly exceeded the average regional indicators in terms of growth rates and was accompanied by a relatively low level of reduction in the number of academic staff, along with Leningrad and Moscow Oblast, as well as the city of Moscow, also include Krasnoyarsk Krai and Tatarstan (middle level of resource dependence), Astrakhan Oblast (prevalence of mining industries over manufacturing ones with an average share of mining industries in GRP) and the Republic of Sakha (Yakutia) characterised by a very high level of resource dependence.

\section{Conclusion}

Thus, the study found no significant specificity of the group of the resourcedependent regions by the educational level of the employed population, as well as by the number of university students. However, the analysis of the educational pattern for 
individual groups of the resource-type regions still allows obtaining some interesting results. The peculiarities of using high-quality human capital (the structure of the employed with higher education) in the studied regions have been identified, and its dependence on their resource specialization has been revealed.

At the same time, according to the parameters of changes in the number of academic staff and the growth in their salaries, it is possible to state that there is a rise in uneven development of the education systems in the resource-type regions, and increase in the universities differentiation that downshifts most of them towards the educational space periphery with a shortage of human and other resources.

The areas of further research may include analysis of the influence of a region's resource dependence level on changes in the educational pattern of employment, as well as the directions and extent of the so-called "educational" migration.

\section{References}

Bravo-Ortega, C., de Gregorio, J. (2005). The Relative Richness of The Poor? Natural Resources, Human Capital, And Economic Growth. Policy, Research working papers; no. WPS3484. Washington, DC: World Bank. Available at: http://documents. worldbank.org/curated/en/618031468779383758/The-relative-richness-of-the-poornatural-resources-human-capital-and-economic-growth (accessed 26 July 2019).

Evans, N., Sawyer, J. (2009). The Mining Boom: Challenges and Opportunities for Small Business in Regional South Australia. In The Australasian Journal of Regional Studies, 15(3), 355.

Franks, D.M., Brereton, D., Moran, C.J. (2010). Managing the Cumulative Impacts of Coal Mining on Regional Communities and Environments in Australia. In Impact Assessment and Project Appraisal, 28(4), 299-312.

Informatsiia dlia vedeniia monitoringa sotsialno-ekonomicheskogo polozheniia sub"ektov Rossiiskoi Federatsii v ianvare - iiune 2019 goda [Information for Monitoring Social and Economic Situation of the Constituent Entities of the Russian Federation in January - June 2019]. Available at: www.gks.ru/free_doc/doc_2019/ monitor/info-stat-06-2019.rar (accessed 1 August 2019).

Itogi federal'nogo statisticheskogo nabliudeniia $v$ sfere oplaty truda otdel'nyh kategorii rabotnikov social'noi sfery $i$ nauki (2018) [The Results of the Federal Statistical Observation in the Field of Wage of Certain Categories of Social Workers and Science]. Available at: http://www.gks.ru/wps/wcm/connect/rosstat_main/rosstat/ ru/statistics/wages/ (accessed 1 August 2019). 
Kurbatova, M.V., Donova, I.V. (2019). Effektivnyi kontrakt v vysshem obrazovanii rezultaty realizatsii proekta [Effective Contract in Higher Education: Some Results of Project Implementation]. In Journal of Institutional Studies, 11(2), 122-145. DOI: 10.17835/2076-6297.2019.11.2.122-145.

Leamer, E.E., Maul, H., Rodriguez, S., Schott, P.K. (1999). Does Natural Resource Abundance Increase Latin American Income Inequality? In Journal of Development Economics, 59, 3-42. DOI: 10.1016/S0304-3878(99)00004-8

Regiony Rossii: Sotsialno-ekonomicheskie pokazateli [Regions of Russia: Socioeconomic Indicators]. (2018). Available at: http://www.gks.ru/bgd/regl/b18_14p/ Main.htm, accessed 1 August 2019.

Rolfe, J., Miles, B., Lockie, S., Ivanova, G. (2007). Lessons from the Social and Economic Impacts of the Mining Boom in the Bowen Basin 2004-2006. In The Australasian Journal of Regional Studies, 13(2), 134.

Semerikova, E.V., Demidova, O.A. (2016). Vzaimodeistvie regionalnykh rynkov truda v Rossii: analiz s pomoshch'iu prostranstvennykh ekonometricheskikh modelei [Interaction of Regional Labour Markets in Russia: Spatial Econometric Analysis]. In Spatial Economics [Prostranstvennaia Ekonomika], 3, 57-80. DOI: 10.14530/ se.2016.3.057-080.

Vasilyeva, O.G. (2012). Vredit li izobilie prirodnykh resursov investitsiiam v obrazovanie? Sluchai rossiiskikh regionov [Does Abundance of Natural Resources Impair Investments in Education? Case of Russian Regions]. In Zhurnal Novoi Ekonomicheskoi Assotsiatsii [Journal of the New Economic Association], 2 (14), 67-81.

\title{
Высшее образование в регионах ресурсного типа
}

\author{
М.В. Курбатова, И.В. Донова \\ Кемеровский государственный университет \\ Россия, 650043, Кемерово, ул. Красная, 6
}

\footnotetext{
В настоящее время усиливается внимание к региональным экономикам ресурсного типа. В рамках изучения проблемы «ресурсного проклятия» во многих работах рассматриваются механизмы возникновения ловушки недоразвития человеческого капитала. В статье предпринята попытка выявить, зависит ли от уровня ресурсности региона развитие региональных систем высшего образования и характеристики накопленного человеческого капитала высокого уровня. Исследование основано на проведенной нечеткой типологизаџии регионов России по двум показателям: доле добывающих отраслей в ВРП и соотношению долей добывающих, обрабатывающих отраслей
} 
и расчета комплексной оченки ресурсной зависимости (по шкале от 0 до 10). Проведенные расчеты позволили выделить 27 ресурсных регионов. Из них было выделено 7 регионов очень высокого уровня ресурсной ориентированности, 6 регионов высокого уровня, 11 регионов среднего уровня, а также 3 региона с преобладанием добывающих отраслей над обрабатывающими при средней доле добывающих отраслей в ВРП. Были проанализированы показатели образовательного уровня занятого населения и специфика его использования (накопленный человеческий капитал), численности студентов вузов (поток человеческого капитала), а также зависимость от уровня ресурсности региона сокращения численности преподавателей и роста их зарплат. Обнаружена зависимость характера использования человеческого капитала высокого уровня от ресурсной специализации регионов. Она проявляется в достаточно высоком образовательном уровне рабочей силь, занятой в добывающих отраслях и в бюджетном секторе и имеющей специальную профессиональную подготовку (т.е. работающих в соответствии с дипломом). При этом по параметрам изменения численности ППС и роста их зарплат можно констатировать усиление неравномерности развития образовательных систем регионов ресурсного типа, рост дифференциачии вузов и вытеснение большинства из них на периферию образовательного пространства с дефицичтом кадрового потенцииала и других ресурсов.

Ключевые слова: высшее образование, регионы ресурсного типа, человеческий капитал, структура занятости.

Грант РФФИ № 19-010-00244 «Институцииональная организаџия рынка труда в регионах ресурсного типа».

Научная спещиальность: 08.00.00 - экономические науки. 